\title{
Effects of Three Biochars as Adsorbents on Soils Adsorbing Ammonium Nitrogen in Biogas Slurry
}

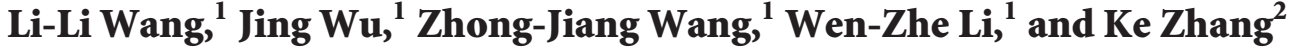 \\ ${ }^{1}$ College of Engineering, Northeast Agricultural University, Harbin 150030, China \\ ${ }^{2}$ Department of Biological and Agricultural Engineering, Kansas State University, Manhattan, KS 66506, USA \\ Correspondence should be addressed to Ke Zhang; zhangke@ksu.edu
}

Received 5 January 2017; Revised 1 May 2017; Accepted 8 June 2017; Published 16 July 2017

Academic Editor: Wenshan Guo

Copyright ( 2017 Li-Li Wang et al. This is an open access article distributed under the Creative Commons Attribution License, which permits unrestricted use, distribution, and reproduction in any medium, provided the original work is properly cited.

\begin{abstract}
The increasing concern of biogas slurry disposal and nitrogen loss in soils has brought back the interest in using biochar as an adsorbent of biogas slurry in soils. Three types of biochars, commercial activated carbon, pyrolysis productions derived from rice husk, and nut shell, were added as adsorbents in two types of soils (sandy and loamy) at solid weight ratio of 5\%, 10\%, 15\%, and 20\% to investigate the effects of biochars on soils adsorbing ammonium nitrogen $\left(\mathrm{NH}_{4}{ }^{+}-\mathrm{N}\right)$ in biogas slurry using oscillation method. There was no difference of $\mathrm{NH}_{4}{ }^{+}-\mathrm{N}$ adsorbability for sand soil and loamy soil. The $\mathrm{NH}_{4}^{+}-\mathrm{N}$ adsorption capacity of soils increased as the additive biochars increased from 0 to $20 \%$. The smaller particle size of biochars led to the shorter stable adsorption time and the better $\mathrm{NH}_{4}{ }^{+}-\mathrm{N}$ adsorption capacity. Commercial activated carbon showed the best $\mathrm{NH}_{4}{ }^{+}-\mathrm{N}$ adsorption capacity in biogas slurry, followed by the nut shell carbon. The rice husk carbon was the worst. The results in this study provide a feasible and cost-effective assessment method of biochars for increasing the $\mathrm{NH}_{4}{ }^{+}-\mathrm{N}$ adsorption capacity of soils in biogas slurry, as well as good insight into effects of different biochars on improving $\mathrm{NH}_{4}{ }^{+}-\mathrm{N}$ adsorption capacity of soils.
\end{abstract}

\section{Introduction}

Biogas derived from anaerobic digestion (AD) of biomass has been comprehensively utilized because of energy production, environmental protection, and favorable ecological cycle $[1,2]$. Many medium and large scale AD facilities have been recently established in worldwide [3-6]. Therefore, the disposal of biogas slurry, a liquid by-product of biogas production, has attracted the attention with rapid expansion of biogas industries. Some researchers utilized biogas slurry as a superior organic fertilizer in arable crop production [7]. Biogas slurry offers many advantages including (1) promoting the granular structure formation of soil and improving the physical and chemical properties of soil $[8,9]$; (2) providing nitrogen, phosphorus, potassium, amino acid, auxin, and ionmicroelement for crop's sprouting and growing [10]. Moreover, biogas slurry has higher inorganic nitrogen content and the mineralization rate than biogas residue (solid remains of digestate after solid-liquid separation) [11]. However, more than $90 \%$ weight of biogas slurry is liquid, where up to
$70 \%$ of total nitrogen $(\mathrm{TN})$ is $\mathrm{NH}_{4}{ }^{+}$-N. It may reduce soil viscosity transferring nitrogen to deep soil layers and resulting in a contamination threat to groundwater. Moreover, a considerable amount of nitrogen can also be released into the air through ammonia $\left(\mathrm{NH}_{3}\right)$ volatilization and nitrous oxide $\left(\mathrm{N}_{2} \mathrm{O}\right)$, creating odor nuisance and reducing fertilizer efficiency [12-17]. Previous studies reported that only $13.38-34.72 \%$ nitrogen of biogas slurry can be effectively used by Pennisetum $[18,19]$, whereas $\mathrm{NH}_{3}$ volatilization increased as increase of digestate applied, and $\mathrm{NH}_{4}{ }^{+}-\mathrm{N}$ was a key factor for $\mathrm{NH}_{3}$ volatilization loss [20,21].

Biochar, a carbonaceous product, is produced in the pyrolysis process of organic biomass with limited or no oxygen [22]. It is estimated that implementing a globally sustainable biochar program is able to offset approximately $12 \%$ of the current global anthropogenic $\mathrm{CO}_{2}-\mathrm{C}$ equivalent emissions [23, 24]. Therefore, biochar is recognized as a soil amendment in improving the water storage capacity of soil and the physical, chemical, and biological properties of soil [25-28]. In addition, biochar has been proved to improve 
TABLE 1: Characteristics of soils used in this assay.

\begin{tabular}{lcc}
\hline Parameters & Sandy soil $\left(\mathrm{T}_{1}\right)$ & Loamy soil $\left(\mathrm{T}_{2}\right)$ \\
\hline Total solid (\%) & 96.40 & 97.26 \\
Organic matter (\%) & 6.39 & 8.24 \\
Field capacity (\%) & 21.22 & 23.16 \\
Sand content $(>0.074 \mathrm{~mm}, \%)$ & 93.37 & 86.48 \\
$\mathrm{pH}$ & 7.3 & 7.6 \\
\hline
\end{tabular}

the nitrogen dynamics in soil by altering the migration and transformation processes due to good nitrogen adsorption $[29,30]$. Moreover, biochar can decrease the runoff and leaching loss of nitrogen to make the nutrient more available for crops [31-33]. The maximum $\mathrm{NH}_{4}{ }^{+}-\mathrm{N}$ adsorption capacity of biochar was investigated to be $909 \mathrm{mg} \cdot \mathrm{kg}^{-1}$, and the adsorbed $\mathrm{NH}_{4}{ }^{+}-\mathrm{N}$ was exchangeable and available [34]. In addition, biochar is also known to reduce nitrogen loss from the soil in terms of $\mathrm{N}_{2} \mathrm{O}$ emission and $\mathrm{NH}_{3}$ volatilization $[35,36] . \mathrm{NH}_{3}$ volatilization was almost reduced up to $70 \%$ using poultry litter biochar and macadamia nut shell biochar [37].

For these reasons, there are many efforts to study the use of biochars for decreasing nitrogen loss of biogas slurry. Bruun et al. [38] reported that wheat straw biochar can reduce the $\mathrm{N}_{2} \mathrm{O}$ emission of biogas slurry effectively. Biogas residue biochar activated chemically can adsorb $\mathrm{NH}_{4}{ }^{+}-\mathrm{N}$ in biogas slurry [39]. However, Guo et al. [40] suggested that both biogas slurry and cow dung biochar have the potential to pollute groundwater when leaching happens regardless the adsorbent capacity of biochar. There are also some positive researches on the application of subabul (Leucaena leucocephala) biochar and biogas slurry to improve soil properties and crop growth [41]. Nevertheless, the effects of different biochars on nitrogen, especially $\mathrm{NH}_{4}{ }^{+}-\mathrm{N}$ adsorption for biogas slurry in different soils, are not fully understood yet. The objective of this study is to evaluate the effects of three biochars (commercial activated carbon, rice husk carbon, and nut shell carbon) on $\mathrm{NH}_{4}{ }^{+}-\mathrm{N}$ adsorption capacity of two soils (sandy and loamy) in biogas slurry on laboratory scale.

\section{Materials and Methods}

2.1. Materials. The sandy soil $\left(\mathrm{T}_{1}\right)$ and loamy soil $\left(\mathrm{T}_{2}\right)$ used in this experiment were from the Xingfu Village $\left(45^{\circ} 53^{\prime} \mathrm{N}\right.$, $125^{\circ} 07^{\prime} \mathrm{E}$ ) of Maoxing Town, Zhaoyuan County, and the experimental field $\left(45^{\circ} 42^{\prime} \mathrm{N}, 126^{\circ} 46^{\prime} \mathrm{E}\right)$ behind the School of Life Sciences in Northeast Agricultural University, respectively. All soils were collected within the top $20 \mathrm{~cm}$ of the plough layer and then were crumbled to pass a $2 \mathrm{~cm}$ sieve and air-dried. The main characteristics of soils are shown in Table 1.

The three types of biochars applied in this experiment were commercial activated carbon $\left(\mathrm{C}_{1}\right)$, rice husk carbon $\left(\mathrm{C}_{2}\right)$, and nut shell carbon $\left(\mathrm{C}_{3}\right)$. The common granular commercial activated carbon (Tianjian, China) bought from local material market was ground into $2 \mathrm{~mm}, 1 \mathrm{~mm}$, and $0.5 \mathrm{~mm}$, respectively, and dried at $105^{\circ} \mathrm{C}$ overnight. The rice husk carbon and nut shell carbon were from pure rice husk and pure pine nut shell pyrolyzed at $600^{\circ} \mathrm{C}$ in a tube furnace (OTF$1200 \mathrm{X}-100)$, where the nitrogen flow rate is $16.7 \mathrm{~mL} \cdot \mathrm{min}^{-1}$ at atmospheric pressure with a retention time of $6 \mathrm{~h}$ [42]. The rice husk carbon and nut shell carbon produced were cooled down overnight under the same nitrogen flow, then ground passing through $0.5 \mathrm{~mm}$ sieve, and dried at $105^{\circ} \mathrm{C}$ overnight. The $\mathrm{pH}$, ammonium nitrogen, and BET surface areas of three biochars are displayed in Table 2. Their other characteristics including porous size distributions and surface functional groups were discussed in Results and Discussion (Section 3.1).

The original biogas slurry was from a pilot-scale $\mathrm{AD}$ facility in Northeast Agricultural University, in which cow manure had been digested as feedstock for more than 60 days. The initial AD concentration of total solid was $8 \%$. The fermentation temperature was $35^{\circ} \mathrm{C}$. The digestate was centrifuged at the rotate speed of $3000 \mathrm{rpm}$ for $3 \mathrm{~min}$; then the liquid was taken out and kept in refrigerator. The main characteristics of original biogas slurry are shown in Table 2.

2.2. Experimental Design and Procedure. Three biochars were mixed thoroughly with sandy soil and loamy soil at weight ratio of $5 \%, 10 \%, 15 \%$, and $20 \%$, respectively. The details of combinations of biochars and soils were $100 \%$ pure soils $\left(\mathrm{T}_{1}, \mathrm{~T}_{2}\right), 100 \%$ pure biochars $\left(\mathrm{C}_{1}-100 \%, \mathrm{C}_{2}-100 \%, \mathrm{C}_{3}-100 \%\right)$, $5 \%$ biochars and $95 \%$ soils $\left(\mathrm{C}_{1} \mathrm{~T}_{1}-5 \%, \mathrm{C}_{2} \mathrm{~T}_{1}-5 \%, \mathrm{C}_{2} \mathrm{~T}_{2}-5 \%\right.$, $\mathrm{C}_{3} \mathrm{~T}_{1}-5 \%$, and $\left.\mathrm{C}_{3} \mathrm{~T}_{2}-5 \%\right), 10 \%$ biochars and $90 \%$ soils $\left(\mathrm{C}_{1} \mathrm{~T}_{1}\right.$ $10 \%, \mathrm{C}_{2} \mathrm{~T}_{1}-10 \%, \mathrm{C}_{2} \mathrm{~T}_{2}-10 \%, \mathrm{C}_{3} \mathrm{~T}_{1}-10 \%$, and $\left.\mathrm{C}_{3} \mathrm{~T}_{2}-10 \%\right), 15 \%$ biochars and $85 \%$ soils $\left(\mathrm{C}_{1} \mathrm{~T}_{1}-15 \%, \mathrm{C}_{2} \mathrm{~T}_{1}-15 \%, \mathrm{C}_{2} \mathrm{~T}_{2}-15 \%\right.$, $\mathrm{C}_{3} \mathrm{~T}_{1}-15 \%$, and $\mathrm{C}_{3} \mathrm{~T}_{2}-15 \%$ ), and $20 \%$ biochars and $80 \%$ soils $\left(\mathrm{C}_{1} \mathrm{~T}_{1}-20 \%, \mathrm{C}_{2} \mathrm{~T}_{1}-20 \%, \mathrm{C}_{2} \mathrm{~T}_{2}-20 \%, \mathrm{C}_{3} \mathrm{~T}_{1}-20 \%\right.$, and $\mathrm{C}_{3} \mathrm{~T}_{2}-$ $20 \%)$. Soils with no biochars were as the controls. $1 \mathrm{~g}$ combination of biochars and soils was mixed with $30 \mathrm{ml}$ biogas slurry in a $100 \mathrm{ml}$ centrifuge tube, then covered a seal lid, and mixed thorough. 27 replications of each mixed tube were oscillated in a temperature-controlled oscillator at $25^{\circ} \mathrm{C}$ for $120 \mathrm{rpm}$. Three tubes were taken out to centrifuge for $3 \mathrm{~min}$ with $4000 \mathrm{rpm}$ when oscillation time was at 5, 10, 20, 40, $60,80,120,180$, and $240 \mathrm{~min}$ separately to measure $\mathrm{NH}_{4}{ }^{+}-$ $\mathrm{N}$ content in the supernatant. $\mathrm{NH}_{4}{ }^{+}-\mathrm{N}$ content of solution $\left(A_{1}\right)$ was the average of $\mathrm{NH}_{4}{ }^{+}-\mathrm{N}$ contents from three tubes. $\mathrm{NH}_{4}{ }^{+}-\mathrm{N}$ adsorption content (AC) was the difference between $\mathrm{NH}_{4}{ }^{+}-\mathrm{N}$ content of original biogas slurry $\left(A_{0}\right)$ and $A_{1}$.

$$
\mathrm{AC}=A_{0}-A_{1}
$$

$\mathrm{NH}_{4}{ }^{+}-\mathrm{N}$ adsorption proportion at different time point (ANAP) was calculated by the following equation, respectively:

$$
\operatorname{ANAP}(\%)=\left(\mathrm{AC} \div A_{0}\right) \times 100 \%
$$

2.3. Analytical Methods. The total solid (TS) of soil and biogas slurry was measured according to the oven-dried method at $105 \pm 5^{\circ} \mathrm{C}$ for $8-12 \mathrm{~h}$ [19]. The soil organic matter (SOM) was measured based on the loss of dry mass after sample ignition at $375^{\circ} \mathrm{C}$ for 16 hours [43, 44]. The field capacity of soil was measured by $100 \mathrm{~cm}^{3}$ cutting ring according to Welcox method $[45,46]$. Soil $\mathrm{pH}$ was measured 
TABLE 2: Characteristics of biochars and biogas slurry used in this assay.

\begin{tabular}{lccc}
\hline Parameters & $\mathrm{pH}$ & Ammonium nitrogen $\left(\mathrm{mg} \cdot \mathrm{kg}^{-1}\right)$ & BET surface $\left.\operatorname{areas}^{2} \mathrm{~m}^{2} / \mathrm{g}\right)$ \\
\hline Activated carbon & 7.7 & 36.66 & 872.987 \\
Rice husk carbon & 9.1 & 58.64 & 3.176 \\
Nut shell carbon & 8.6 & 46.58 & 144.194 \\
Biogas slurry & 7.9 & 1201.40 & - \\
\hline
\end{tabular}

in a $1: 5 \mathrm{soil} /$ water suspension by potentiometric method. The $\mathrm{pH}$ of three biochars were measured in a 1:10 carbon/water suspension according to the standard test method for granular activated carbon (GB/T 7702.16-1997). The surface areas, porous size distributions, and surface functional groups of three biochars were measured by Surface Area and Mesopore Size Analyzer (JW-BK112T) and FT-IR spectrometer (Perkin Elmer, Spectrum 400, FT-IR/FT-NIR spectrometer), respectively. Biogas slurry $\mathrm{pH}$ was determined directly by $\mathrm{pH}$ meter (Sartorius Basic $\mathrm{pH}$ Meter, Germany). $\mathrm{NH}_{4}{ }^{+}-\mathrm{N}$ content of soil, biochar, and biogas slurry was measured by auto Kjeldahl nitrogen analysis equipment (Kjeldahl 2300, FOSS, Denmark) according to standard methods modified by Federation and Water Environmental American Public Health Association [47].

2.4. Statistical Analyses. Correlation analyses and one-way ANOVA were carried out using SPSS (version 19.0, IBM, Armonk, NY, USA) at 0.05 level. All measurements have been conducted in triplicate; the average values and the standard deviations were reported.

\section{Results and Discussion}

3.1. Characterization of Commercial Activated Carbon, Rice Husk Carbon, and Nut Shell Carbon. The surface areas, pore size distribution curves, and FT-IR spectral scan of three biochars are shown in Table 2, Figures 1 and 2, respectively.

The BET surface areas of commercial activated carbon, rice husk carbon, and nut shell carbon were $872.987 \mathrm{~m}^{2} / \mathrm{g}$, $3.176 \mathrm{~m}^{2} / \mathrm{g}$, and $144.194 \mathrm{~m}^{2} / \mathrm{g}$, respectively (Table 2). The BET surface areas of commercial activated carbon were much higher than rice husk carbon and nut shell carbon. Therefore, the adsorption capacity of commercial activated carbon was much better than rice husk carbon and nut shell carbon. However, the BET surface areas of rice husk carbon were less than $10 \mathrm{~m}^{2} / \mathrm{g}$, indicating that the biochar from rice husk did not have typical micropores or pores. These results were also further demonstrated by the pore size distributions of the three biochars (Figure 1). The pore volumes of commercial activated carbon were the largest, followed by nut shell carbon. It is noted that the rice husk carbon had few micropores less than $2 \mathrm{~nm}$.

As shown in Figure 2, the three biochars showed a sharp spectral peak associating with -OH groups $\left(3450 \mathrm{~cm}^{-1}\right)$. This indicated that the $\mathrm{C}-\mathrm{OH}$ linkages in samples were not stable. In addition, the intensity of the band for conjugated aromatic ring stretching of $C=C$ groups $\left(1616 \mathrm{~cm}^{-1}\right)$ of nut shell carbon changed little, indicating that the aromatic linkages of nut shell carbon were more stable than those of commercial activated carbon and rice husk carbon. Furthermore, the nut shell carbon showed bands for aliphatic chains, including $-\mathrm{CH}_{3}$ and $-\mathrm{CH}_{2}$ - groups $\left(1450 \mathrm{~cm}^{-1}\right)$ because the $\mathrm{C}$ - $\mathrm{H}$ bonds were strong. The sharp spectral peak at approximately $1108 \mathrm{~cm}^{-1}$ was stretching vibration of $\mathrm{C}-\mathrm{O}$ because of the powerful aromatic C-O linkages.

\subsection{Effect of Commercial Activated Carbon with Different} Particle Sizes on Sandy Soil Adsorbing $\mathrm{NH}_{4}{ }^{+} \mathrm{N}$ in Biogas Slurry. In order to investigate the effect of particle sizes of biochar on $\mathrm{NH}_{4}{ }^{+}-\mathrm{N}$ adsorbing capacity of soil in biogas slurry, commercial activated carbon with particle size of $2 \mathrm{~mm}, 1 \mathrm{~mm}$, and $0.5 \mathrm{~mm}$ was mixed with sandy soil to determine ANAPs in biogas slurry. As shown in Figure 3, the ANAPs of pure sandy soil (no commercial activated carbon adding) were negative $(-1.99 \%)$ at $5 \mathrm{~min}$ and reached the maximum (11.83\%) at $10 \mathrm{~min}$ and fluctuated up and went down slightly. This result suggests that the soluble $\mathrm{NH}_{4}{ }^{+}-\mathrm{N}$ in soil affected $\mathrm{NH}_{4}{ }^{+}-\mathrm{N}$ content of sample solution at initial stage; hence, the ANAP decreased conversely at first $5 \mathrm{~min}$. The average ANAP after adsorptive stability $(10 \mathrm{~min})$ was $9.23 \%$.

In Figure 3(a), the ANAPs of the samples with $2 \mathrm{~mm}$ activated carbon show similar trend as pure sandy soil; however, all the samples achieved adsorptive stability at $20 \mathrm{~min}$. The increasing time of adsorptive stability was attributed to the addition of $2 \mathrm{~mm}$ commercial activated carbon. Moreover, all the average ANAPs after adsorptive stability increased with increase of commercial activated carbon at level 0.05 $(r=0.97, P=0.03$, and $n=4)$. The biggest ANAP and the average ANAP of sandy soil with $20 \% 2 \mathrm{~mm}$ commercial activated carbon were $24.64 \%$ and $23.81 \%$, which were higher than those of pure sandy soil by $12.80 \%$ and $14.58 \%$ separately $(F=997.11, P<0.001)$.

Figure 3(b) shows that sandy soil adding $20 \% 1 \mathrm{~mm}$ commercial activated carbon reached stability at $5 \mathrm{~min}$ and then presented slightly decreasing trend at $10 \mathrm{~min}$. Other sandy soil samples, however, reached basic adsorptive stability at $10 \mathrm{~min}$. All the average ANAPs after adsorptive stability were positively correlated to the amount of $1 \mathrm{~mm}$ commercial activated carbon at level $0.05(r=0.96, P=0.05$, and $n=4)$. The highest ANAP and the average ANAP with $20 \%$ $1 \mathrm{~mm}$ commercial activated carbon were $26.09 \%$ and $24.86 \%$, which were higher than those of pure sandy soil by $14.25 \%$ and $15.63 \%$, respectively $(F=1564.38, P<0.001)$.

When the $15 \%$ and $20 \% 0.5 \mathrm{~mm}$ commercial activated carbon were added, the ANAPs of the samples achieved adsorptive stability at $5 \mathrm{~min}$ (Figure $3(\mathrm{c})$ ). However, the 


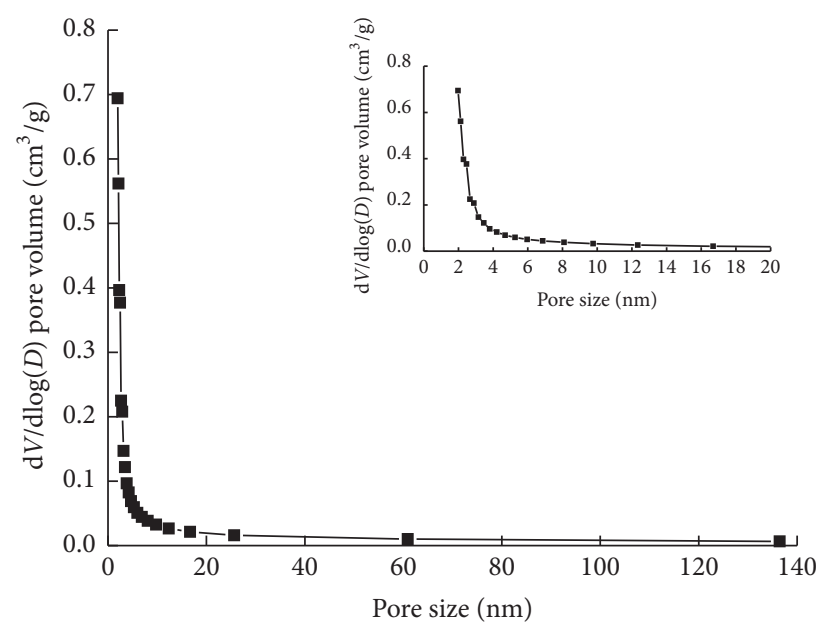

(a) Commercial activated carbon $\left(\mathrm{C}_{1}\right)$

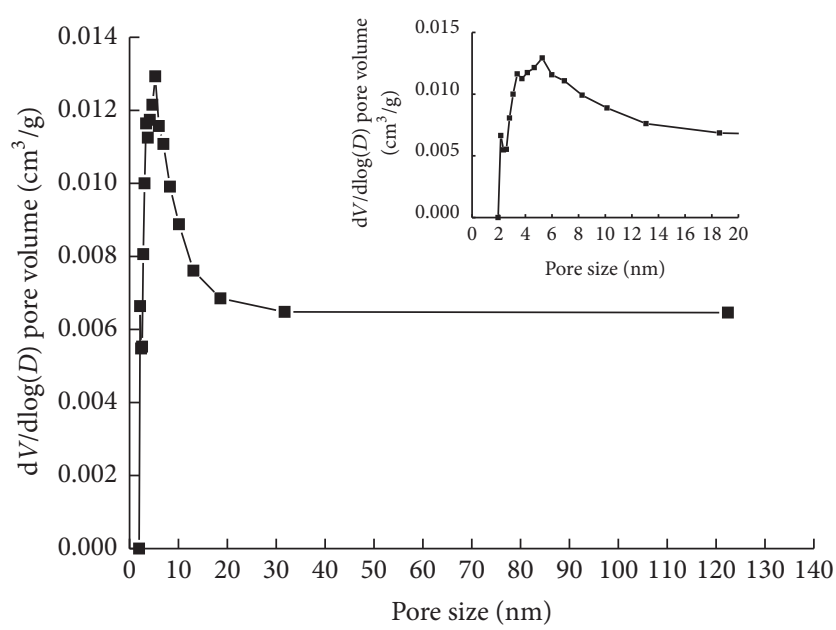

(b) Rice husk carbon $\left(\mathrm{C}_{2}\right)$

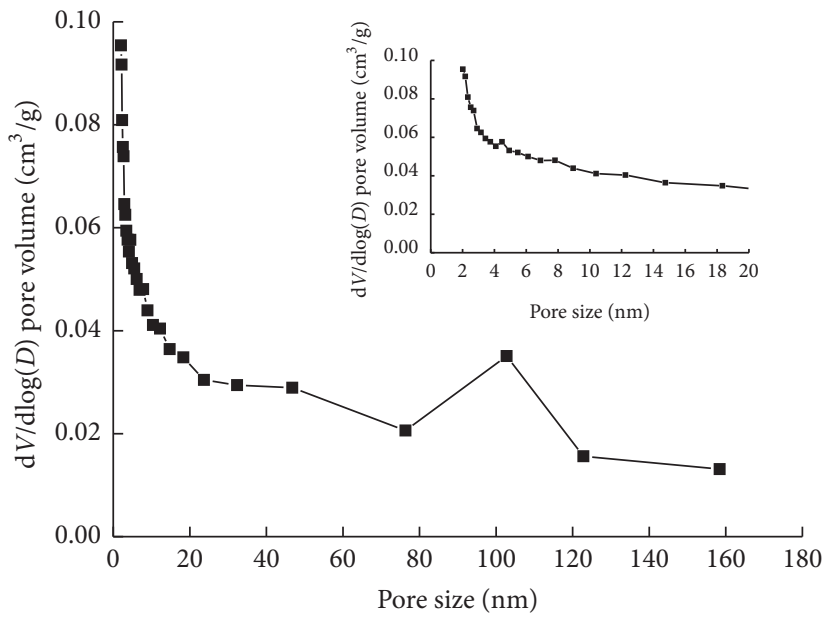

(c) Nut shell carbon $\left(\mathrm{C}_{3}\right)$

FIgURE 1: Pore size distribution curves of commercial activated carbon $\left(\mathrm{C}_{1}\right)$, rice husk carbon $\left(\mathrm{C}_{2}\right)$, and nut shell carbon $\left(\mathrm{C}_{3}\right)$.

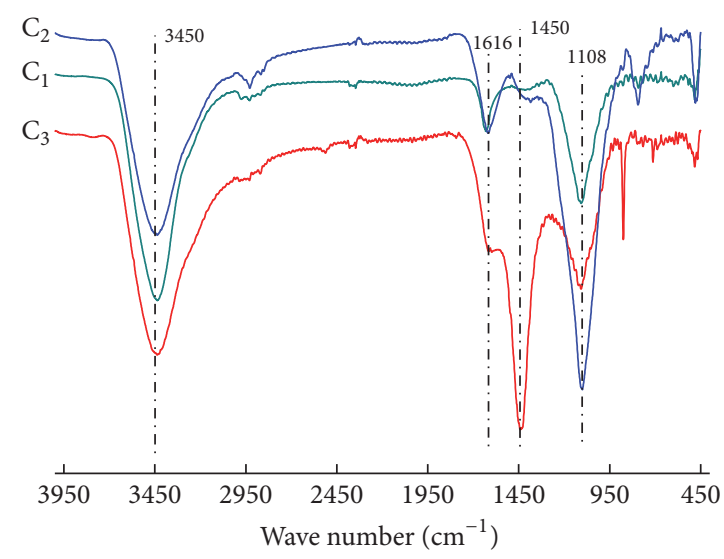

Spectral assignments

$3450-\mathrm{OH}$

$1616-\mathrm{C}=\mathrm{C}-$

$1450-\mathrm{CH}_{3},-\mathrm{CH}_{2}-$

1108 -C-O-

FIGURE 2: FT-IR spectral scan of commercial activated carbon $\left(C_{1}\right)$, rice husk carbon $\left(C_{2}\right)$, and nut shell carbon $\left(C_{3}\right)$. 


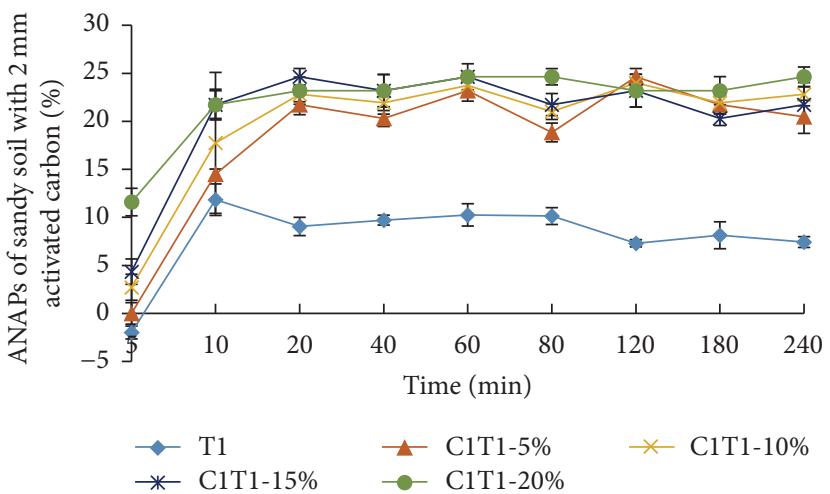

(a) $2 \mathrm{~mm}$ particle size

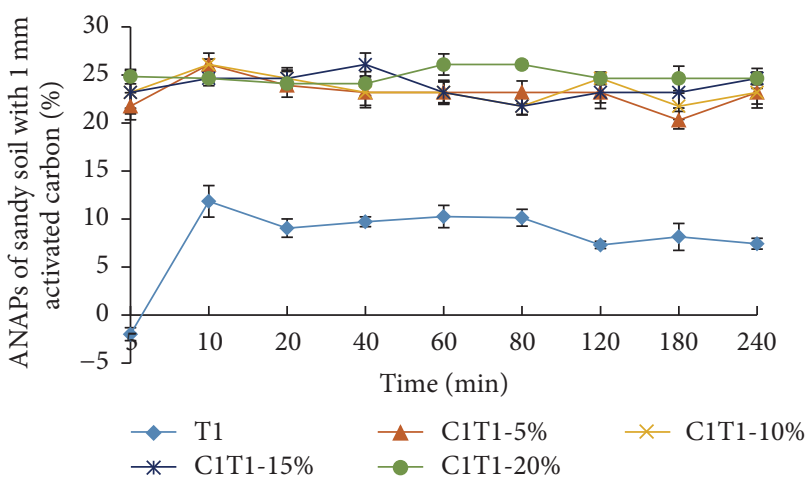

(b) $1 \mathrm{~mm}$ particle size

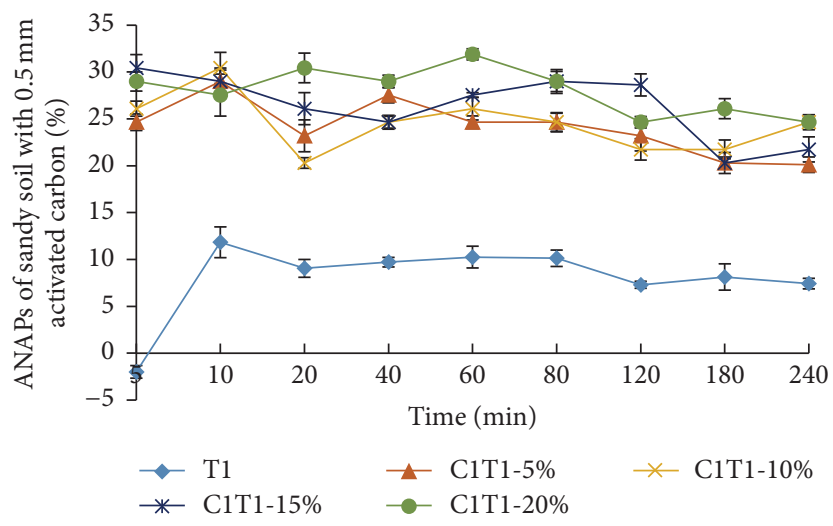

(c) $0.5 \mathrm{~mm}$ particle size

Figure 3: Effects of commercial activated carbon $\left(\mathrm{C}_{1}\right)$ on sandy soil adsorbing $\mathrm{NH}_{4}{ }^{+}-\mathrm{N}$ in biogas slurry when the particle sizes of activated carbon were $2 \mathrm{~mm}, 1 \mathrm{~mm}$, and $0.5 \mathrm{~mm}$.

other samples with 5\% and $10 \%$ commercial activated carbon achieved basic adsorptive stability at $10 \mathrm{~min}$ and decreased significantly at $20 \mathrm{~min}$. All the ANAPs of $0.5 \mathrm{~mm}$ showed relatively higher wave than those of 1 and $2 \mathrm{~mm}$. All the average ANAPs after adsorptive stability were significantly correlated to the amount of $0.5 \mathrm{~mm}$ commercial activated carbon at level $0.05(r=0.96, P=0.04$, and $n=4)$. The biggest ANAP and the average ANAP of sandy soil with $20 \% 0.5 \mathrm{~mm}$ commercial activated carbon were $31.89 \%$ and $28.03 \%$, which were higher than those of pure sandy soil by $20.05 \%$ and $18.79 \%$, respectively $(F=898.65, P<0.001)$.

To sum up, all the ANAPs of sandy soil achieved adsorptive stability within $20 \mathrm{~min}$. The average ANAPs after adsorptive stability increased with the additive amount of commercial activated carbon increased, indicating commercial activated carbon was able to enhance the $\mathrm{NH}_{4}{ }^{+}-\mathrm{N}$ adsorption capacity of sandy soil in biogas slurry and the amount of commercial activated carbon added was a key factor. Commercial activated carbon adsorbs $\mathrm{NH}_{4}{ }^{+}-\mathrm{N}$ in liquid well due to its larger specific surface areas and better pores structure [48-51]. This result was also supported by the actual characterization of commercial activated carbon including surface areas and pore size distributions (Table 2 and Figure 1). Meanwhile, the effects of particle sizes of commercial activated carbon on sandy soil adsorbing $\mathrm{NH}_{4}{ }^{+}-$ $\mathrm{N}$ in biogas slurry were significantly different (Figure 3). All the ANAPs after adsorptive stability significantly increased as decrease of the particle size of commercial activated carbon and $P<0.01$. Moreover, the time of achieving adsorptive stability was less when the particle sizes were $1 \mathrm{~mm}$ and $0.5 \mathrm{~mm}$. Therefore, the particle size of commercial activated carbon was another important factor for improving the $\mathrm{NH}_{4}{ }^{+}-\mathrm{N}$ adsorption capacity of sandy soil. This result was in agreement with some studies on commercial activated carbon adsorbing other organic matter such as phenol, chromium, and humic acid [52-54]. So the smaller commercial activated carbon was, the better its adsorption capacity was, and the more influential its effects on sandy soil adsorbing $\mathrm{NH}_{4}{ }^{+}$$\mathrm{N}$ in biogas slurry was $[48,55]$. However, the ANAPs could not be increased significantly by decreasing the particle size of commercial activated carbon at $20 \mathrm{~min}$. Only the samples with $20 \%$ activated carbon were significantly related to the particle sizes at confidence level 0.01. The possible reason was that the time of soil with different amount of commercial activated carbon varied at achieving adsorptive stability (Figure 3). In other words, the ANAPs of those samples with 0.5 and $1 \mathrm{~mm}$ commercial activated carbon achieved adsorptive stability at $5 \mathrm{~min}$ but decreased at $20 \mathrm{~min}$. 


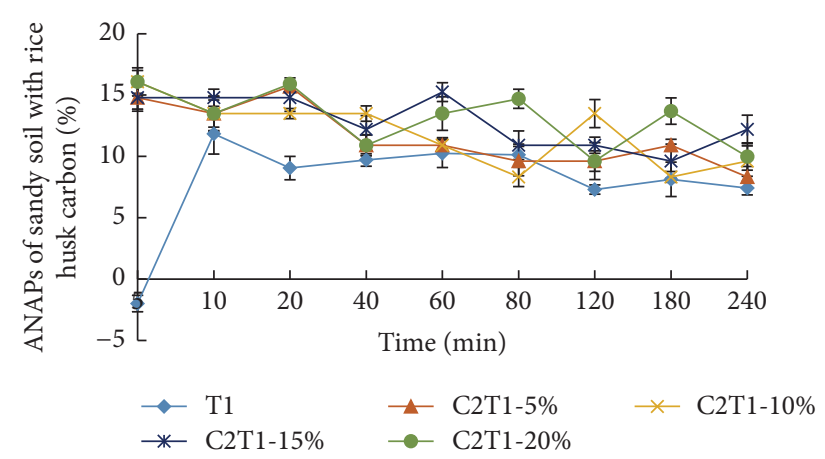

(a) Sandy soil

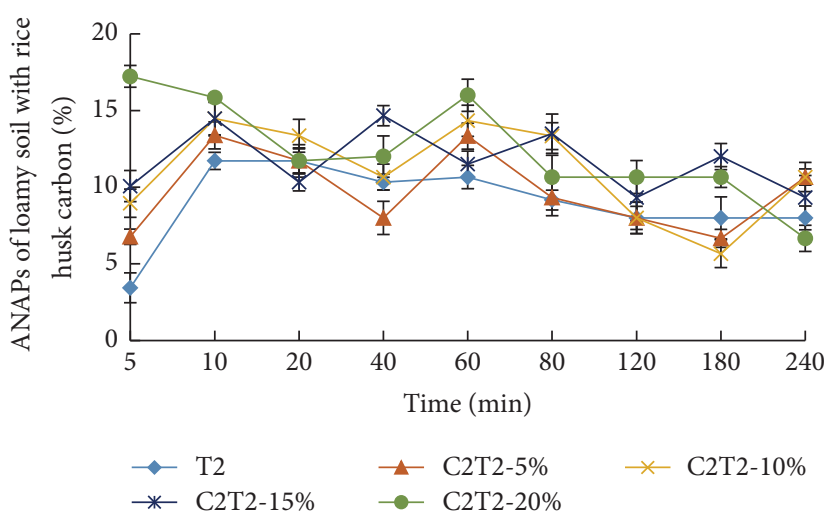

(b) Loamy soil

FIgURE 4: Effects of rice husk carbon $\left(\mathrm{C}_{2}\right)$ on soil adsorbing $\mathrm{NH}_{4}{ }^{+}-\mathrm{N}$ in biogas slurry.

However, the ANAPs of the samples with $2 \mathrm{~mm}$ commercial activated carbon just achieved adsorptive stability at $20 \mathrm{~min}$ and were high relatively. It is noted that the optimal condition for improving the ANAPs of sandy soil was the particle size of $0.5 \mathrm{~mm}$ and the adding amount of $20 \%$.

3.3. Effects of Biochars on Different Soils Adsorbing $\mathrm{NH}_{4}{ }^{+}-\mathrm{N}$ in Biogas Slurry. Based on the optimal particle size mentioned above, particle size of $0.5 \mathrm{~mm}$ was selected in this study to investigate the effects of rice husk carbon and nut shell carbon on sandy soil and loamy soil adsorbing $\mathrm{NH}_{4}{ }^{+}-\mathrm{N}$ in biogas slurry.

Figure 4(a) shows the effects of rice husk carbon on sandy soil adsorbing $\mathrm{NH}_{4}{ }^{+}-\mathrm{N}$ in biogas slurry. ANAPs of the samples with rice husk carbon achieved adsorptive stability at $5 \mathrm{~min}$ and then fluctuated up and went down slightly. The whole trend was a little declined. All the average ANAPs after adsorptive stability increased significantly as increase of rice husk carbon at level $0.05(r=0.98, P=0.03$, and $n=4)$. The biggest ANAP and the average ANAP of sandy soil with $20 \%$ rice husk carbon were $16.08 \%$ and $13.10 \%$, which were higher than those of pure sandy soil by $4.24 \%$ and $3.87 \%$, respectively $(F=40.59, P<0.001)$. On the other hand, the ANAPs of pure loamy soil reached maximum (11.72\%) at $10 \mathrm{~min}$, then fluctuated up, and went down slightly and dropped downtrend at $80 \mathrm{~min}$ and $120 \mathrm{~min}$ apparently (Figure 4(b)). The average ANAP after adsorptive stability was $9.70 \%$ for loamy soil. Moreover, the ANAPs of loamy soil with rice husk carbon fluctuated up and down obviously and the whole trend declined slightly as well. The samples with 5\%,10\%, and 15\% additive proportion achieved adsorptive stability at $10 \mathrm{~min}$, whereas the sample with $20 \%$ additive proportion reached adsorptive stability at $5 \mathrm{~min}$. All the average ANAPs after adsorptive stability increased significantly with increase of rice husk carbon at level $0.05(r=0.97, P=0.03$, and $n=4)$. The biggest ANAP and the average ANAP of loamy soil with $20 \%$ rice husk carbon were $17.23 \%$ and $12.38 \%$, which were higher than those of the pure loamy soil by $5.52 \%$ and $2.69 \%$, respectively $(F=12.61, P<0.001)$.
The sandy soil with 5\% nut shell carbon achieved adsorptive stability at $10 \mathrm{~min}$ and then fluctuated up and went down slightly, as illustrated in Figure 5(a). Nevertheless, the samples with $10 \%, 15 \%$, and $20 \%$ nut shell carbon achieved adsorptive stability at $5 \mathrm{~min}$ and then fluctuated slightly. Furthermore, all the average ANAPs after adsorptive stability significantly increased as increase of nut shell carbon at level $0.01(r=0.99$, $P=0.01$, and $n=4)$. The biggest ANAP and the average ANAP of the sandy soil adding $20 \%$ nut shell carbon were $19.95 \%$ and $16.20 \%$, which were higher than those of the pure sandy soil by $8.11 \%$ and $6.97 \%$ separately $(F=148.38, P<$ 0.001).

As demonstrated in Figure 5(b), the loamy soil adding $5 \%, 10 \%$, and $15 \%$ nut shell carbon achieved adsorptive stability at $10 \mathrm{~min}$ and then fluctuated up and went down slightly, while the loamy soil adding $20 \%$ nut shell carbon reached adsorptiver stability at $5 \mathrm{~min}$ and then started to fluctuate slightly. All the average ANAPs after adsorptive stability increased with increase of nut shell carbon and were significantly correlated to the additive proportion at level 0.01 ( $r=0.99, P=0.01$, and $n=4)$. The biggest ANAP and the average ANAP of loamy soil with $20 \%$ nut shell carbon were $18.60 \%$ and $17.73 \%$, which were higher than those of the pure loamy soil by $6.88 \%$ and $8.03 \%$, respectively $(F=413.40$, $P<0.001)$.

As also shown in Figures 4 and 5, effects of rice husk carbon and nut shell carbon on sandy soil at 5 min were more influential than those on loamy soil. Exception was that the ANAPs of loamy soil adding 20\% rice husk carbon were higher than those of sandy soil. This result indicated that both rice husk carbon and nut shell carbon could effectively increase the $\mathrm{NH}_{4}{ }^{+}-\mathrm{N}$ adsorption capacity of sandy soil at the initial period of adsorption. $\mathrm{NH}_{4}{ }^{+}-\mathrm{N}$ of biogas slurry might be adsorbed quickly after the biogas slurry had been applied into sandy soil. This study can provide further evidence that biochars are more favorable for $\mathrm{NH}_{4}{ }^{+}-\mathrm{N}$ control of sandy soil or other relative barren soils $[56,57]$. Furthermore, when $10 \%$ and $20 \%$ of rice husk carbon were added, the ANAPs of loamy soil were higher than those of sandy soil. However, similar 


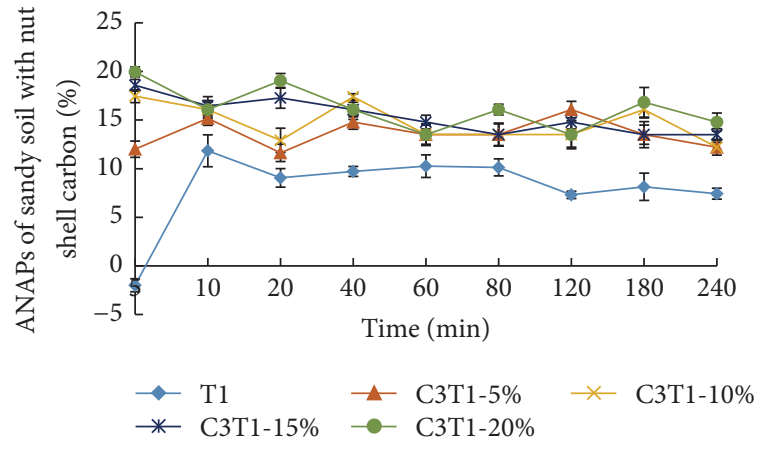

(a) Sandy soil

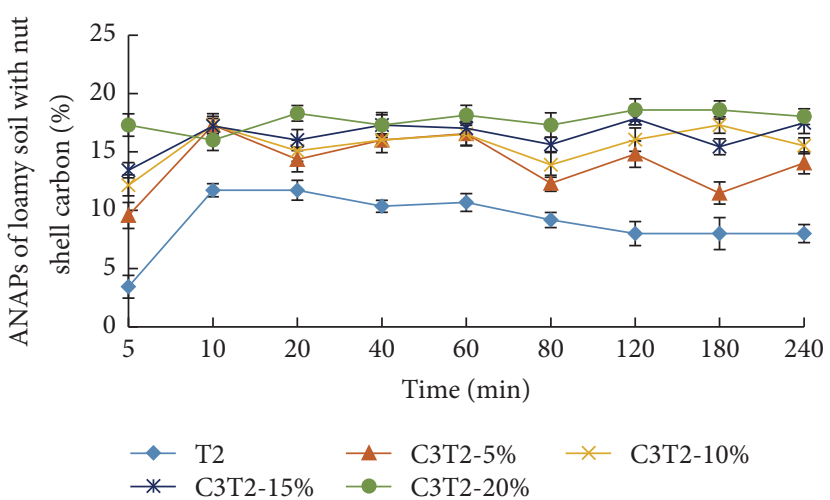

(b) Loamy soil

Figure 5: Effects of nut shell carbon $\left(\mathrm{C}_{3}\right)$ on soil adsorbing $\mathrm{NH}_{4}{ }^{+}-\mathrm{N}$ in biogas slurry.

trend was found for $5 \%, 10 \%$, and $15 \%$ nut shell carbon except for $20 \%$.

To sum up, all the ANAPs of comparative samples with rice husk carbon and nut shell carbon achieved adsorptive stability within $10 \mathrm{~min}$. The average ANAPs after adsorptive stability increased as increase of the two types of biochars, indicating that both rice husk carbon and nut shell carbon could increase the $\mathrm{NH}_{4}{ }^{+}-\mathrm{N}$ adsorption capacity of sandy soil and loamy soil in biogas slurry and the amount of biochars added was an essential factor. It is in agreement with the $\mathrm{NH}_{4}{ }^{+}-\mathrm{N}$ adsorption effects of the above commercial activated carbon and other biochars reported previously, such as straw carbon, charcoal, and corn-stalk biochar [34, 56, 5862]. It is noted that different biochars have similar $\mathrm{NH}_{4}{ }^{+}$$\mathrm{N}$ adsorption effects; thus, biochars are favorable feedstock for decreasing the nitrogen loss in soils and enhancing the nitrogen utilization $[33,36]$. The results can lay a solid foundation for further investigation on effects of biochars on the nitrogen retention of biogas slurry and the effective utilization of biogas slurry in soils.

Moreover, the ANAPs of pure loamy soil were higher than those of pure sandy soil in first 10 min adsorption process (Figures 4 and 5). Both pure soil samples as controls showed downward trend after reaching adsorptive stability. The downward trend of pure sandy soil declined at $20 \mathrm{~min}$ and $120 \mathrm{~min}$ apparently, whereas that of pure loamy soil declined at $80 \mathrm{~min}$ and $120 \mathrm{~min}$ obviously. There is no significant difference on the average ANAPs between pure sand soil and pure loamy soil $(F=0.89 P=0.35)$, indicating there was no difference of $\mathrm{NH}_{4}{ }^{+}-\mathrm{N}$ adsorbability for sand soil and loamy soil. However, previous publications reported that the clay particle content of loamy soil was more than that of sandy soil leading to better $\mathrm{NH}_{4}{ }^{+}-\mathrm{N}$ adsorption capacity [63-65]. Additionally, comparisons of different pure biochars adsorbing $\mathrm{NH}_{4}{ }^{+}-\mathrm{N}$ in biogas slurry are shown in Figure 6 . The three pure biochars reached adsorptive stability at $10 \mathrm{~min}$ and then fluctuated up and down slightly. The rank of average ANAPs after achieving adsorptive stability was as follows: commercial activated carbon (24.64\%), nut

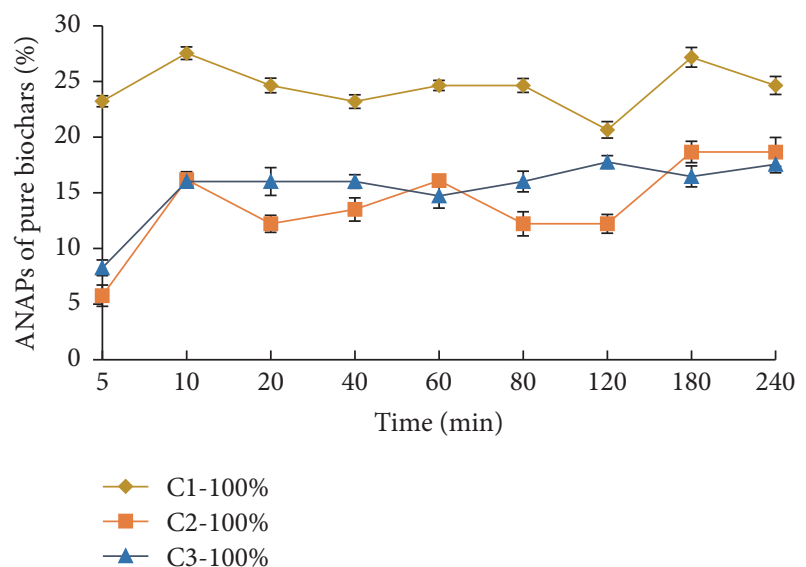

Figure 6: Comparison of different biochars adsorbing $\mathrm{NH}_{4}{ }^{+}-\mathrm{N}$ in biogas slurry.

shell carbon (16.32\%), and rice husk carbon (14.97\%). Oneway ANOVA shows that the average ANAPs of commercial activated carbon were significantly higher than rice husk carbon and nut shell carbon $(F=143.63 P<0.001)$. Moreover, the average ANAPs of rice husk carbon have larger variation $(2.79 \%)$ and were lower than that of nut shell carbon ( $F=4.81 P=0.03)$. Thus, the effects of rice husk carbon on soil adsorbing $\mathrm{NH}_{4}{ }^{+}-\mathrm{N}$ in biogas slurry were worse than that of nut shell carbon (Figures 4 and 5). The findings were actually supported by the characterization of rice husk carbon and nut shell carbon (Table 1, Figures 1 and 2) and other studies on rice husk carbon conducted by Kizito et al. [62, 66-68]. In their studies, the adsorption capacity of rice husk carbon was worse than that of coconut shell carbon, straw carbon, and charcoal because the ash content of rice husk carbon was relatively high. At present, there are some treatments to improve the adsorptive capacity of rice husk carbon, such as ash content reduction and activation [6971]. Nevertheless, treatments increase the costs limiting the application of rice husk carbon as agriculture residual. 


\section{Conclusions}

The ANAPs of all the samples showed similar trend: fluctuating up and going down slightly after reaching adsorptive stability. The adsorptive stability of $\mathrm{NH}_{4}{ }^{+}-\mathrm{N}$ was positively correlated to the adding amount of biochars in soils. The soils adding 20\% biochars showed optimal adsorptive ability of $\mathrm{NH}_{4}{ }^{+}-\mathrm{N}$. Three types of biochars had significant effects on improving adsorptive ability of $\mathrm{NH}_{4}{ }^{+}-\mathrm{N}$, although both pure sandy soil and loamy soil can adsorb $\mathrm{NH}_{4}{ }^{+}-\mathrm{N}$ in biogas slurry by themselves actually. Commercial activated carbon added in sandy soil showed the best adsorptive ability of $\mathrm{NH}_{4}{ }^{+}-\mathrm{N}$, followed by nut shell carbon. And rice husk carbon was the worst. Particle size of commercial activated carbon played an important role not only in increasing the ANAPs of soil but also in boosting the adsorption speeds. Biochars could also effectively increase the $\mathrm{NH}_{4}{ }^{+}-\mathrm{N}$ adsorption capacity of sandy soil at the initial period of adsorption. There was no difference of $\mathrm{NH}_{4}{ }^{+}-\mathrm{N}$ adsorbability for sand soil and loamy soil.

In conclusion, the oscillation adsorption experiments are suitable for studying effects of biochars on soils adsorbing $\mathrm{NH}_{4}{ }^{+}-\mathrm{N}$ in biogas slurry. The results in this study can lay a solid foundation for further investigation on effects of biochars on the nitrogen retention of biogas slurry and the effective utilization of biogas slurry in soil.

\section{Disclosure}

The authors confirm that the manuscript has been read and approved by all named authors and that there are no other persons who satisfied the criteria for authorship but are not listed. The authors further confirm that the order of authors listed in the manuscript has been approved by all of them. The authors confirm that they have given due consideration to the protection of intellectual property associated with this work and that there are no impediments to publication, including the timing of publication, with respect to intellectual property. In so doing the authors confirm that they have followed the regulations of their institutions concerning intellectual property.

\section{Conflicts of Interest}

The authors wish to confirm that there are no known conflicts of interest associated with this publication and there has been no significant financial support for this work that could have influenced its outcome.

\section{Acknowledgments}

This experimental work has been funded by the National Natural Science Foundation of China (no. 51406032), Natural Science Foundation of Heilongjiang Province (no. E201406), Federal Funding from Heilongjiang Province (no. LBH-Z13044), and National High-Tech R\&D Program of China (no. 2014AA022001). The authors would like to thank Professors Xianzhe Zheng and Haiyan Yang for providing their valuable suggestions on the experimental plan and the research paper.

\section{References}

[1] C. Rico, J. L. Rico, and C. Lasa, "Anaerobic digestion of the liquid fraction of dairy manure separated by screw pressing and centrifugation in a upflow anaerobic sludge blanket reactor at $25^{\circ}$ C, Biosystems Engineering, vol. 112, no. 4, pp. 344-351, 2012.

[2] Z. Wang, F. Xu, and Y. Li, "Effects of total ammonia nitrogen concentration on solid-state anaerobic digestion of corn stover," Bioresource Technology, vol. 144, pp. 281-287, 2013.

[3] F. Dang, Y. Bi, and Y. Liu, "Analysis of the large-and-mediumsized biogas projects in europe and comparisons with our country," Chinese Biogas, vol. 32, no. 1, pp. 79-83, 2014.

[4] V. Tiwari, K. Tiwari, and R. Upadhyay, "Effect of crop residues and biogas slurry incorporation in wheat on yield and soil fertility," Journal of the Indian Society of Soil Science, vol. 48, no. 3, pp. 515-520, 2000.

[5] D. Thrän and M. Kaltschmitt, "Competition-supporting or preventing an increased use of bioenergy?" Biotechnology Journal, vol. 2, no. 12, pp. 1514-1524, 2007.

[6] T. Terhoeven-Urselmans, E. Scheller, M. Raubuch, B. Ludwig, and R. G. Joergensen, " $\mathrm{CO}_{2}$ evolution and $\mathrm{N}$ mineralization after biogas slurry application in the field and its yield effects on spring barley," Applied Soil Ecology, vol. 42, no. 3, pp. 297-302, 2009.

[7] E. R. Loria, J. E. Sawyer, D. W. Barker, J. P. Lundvall, and J. C. Lorimor, "Use of anaerobically digested swine manure as a nitrogen source in corn production," Agronomy Journal, vol. 99, no. 4, pp. 1119-1129, 2007.

[8] J. Abubaker, H. Cederlund, V. Arthurson, and M. Pell, "Bacterial community structure and microbial activity in different soils amended with biogas residues and cattle slurry," Applied Soil Ecology, vol. 72, pp. 171-180, 2013.

[9] H. Coban, A. Miltner, F. J. Elling, K.-U. Hinrichs, and M. Kästner, "The contribution of biogas residues to soil organic matter formation and $\mathrm{CO}_{2}$ emissions in an arable soil," Soil Biology and Biochemistry, vol. 86, pp. 108-115, 2015.

[10] R. N. Garg, H. Pathak, D. K. Das, and R. K. Tomar, "Use of flyash and biogas slurry for improving wheat yield and physical properties of soil," Environmental Monitoring and Assessment, vol. 107, no. 1-3, pp. 1-9, 2005.

[11] F. Zhao, Q. Sun, J. Li et al., "Effects of different biogas fertilizers on yield, quality and nitrogen use efficiency of the rape," Journal of Soil and Water Conservation, vol. 24, no. 3, pp. 127-130, 2010.

[12] A. Pacholski, D. Gericke, K. Ni, and H. Kage, "Modelling ammonia emissions after field application of biogas slurries on grassland sites," in Grassland in a changing world, pp. 166-168, 2010.

[13] K. Möller and W. Stinner, "Effects of different manuring systems with and without biogas digestion on soil mineral nitrogen content and on gaseous nitrogen losses (ammonia, nitrous oxides)," European Journal of Agronomy, vol. 30, no. 1, pp. 1-16, 2009.

[14] R. Quakernack, A. Pacholski, A. Techow, A. Herrmann, F. Taube, and H. Kage, "Ammonia volatilization and yield response of energy crops after fertilization with biogas residues in a coastal marsh of Northern Germany," Agriculture, Ecosystems and Environment, vol. 160, pp. 66-74, 2012.

[15] N. Dorno, A. Feilberg, P. Balsari, and T. Nyord, "Nitrous oxide losses from untreated and digested slurry asinfluenced by soil moisture and application method," Biosystems Engineering, vol. 115, no. 4, pp. 423-433, 2013. 
[16] N. Svoboda, F. Taube, B. Wienforth, H. Kage, and A. Herrmann, "Nitrogen leaching losses after biogas residue application to maize," Soil and Tillage Research, vol. 130, pp. 69-80, 2013.

[17] K. Wang, D. Huang, H. Ying, and H. Luo, "Effects of acidification during storage on emissions of methane, ammonia, and hydrogen sulfide from digested pig slurry," Biosystems Engineering, vol. 122, pp. 23-30, 2014.

[18] X. Huang, Q. Huang, X. Yang, B. Weng, Z. Chen, and Z. Zhong, "Efficiency of fertilizing biogas slurry on nitrate accumulation and utilization of Pennisetum," Acta Prataculturae Sinica, p. 8, 2012.

[19] L. Wang, W. Li, Z. Wang, Z. Wang, C. Sui, and Y. Li, "Effects of digestate application depth on soil nitrogen volatilization and vertical distribution," International Journal of Agricultural and Biological Engineering, vol. 9, no. 5, pp. 101-107, 2016.

[20] Z. Wang, K. Cai, L. Wang, G. Wang, and W. Li, "Influence of biogas slurry application on ammonia volatilization and nitrogen infiltration," Transactions of the Chinese Society for Agricultural Machinery, vol. 45, no. 5, pp. 139-144, 2014.

[21] Z. Wang, K. Cai, L. Wang, W. Li, and G. Wang, "Influence of surface application of biogas slurry on ammonia volatilization and dynamic distribution of soil nitrogen," Transactions of the Chinese Society for Agricultural Machinery, vol. 45, no. 7, pp. 139-143, 2014.

[22] H. Yuan, T. Lu, Y. Wang, Y. Chen, and T. Lei, "Sewage sludge biochar: nutrient composition and its effect on the leaching of soil nutrients," Geoderma, vol. 267, pp. 17-23, 2016.

[23] D. Woolf, J. E. Amonette, F. A. Street-Perrott, J. Lehmann, and S. Joseph, "Sustainable biochar to mitigate global climate change," Nature Communications, vol. 1, no. 5, article 56, 2010.

[24] S. Mandal, R. Thangarajan, N. S. Bolan et al., "Biochar-induced concomitant decrease in ammonia volatilization and increase in nitrogen use efficiency by wheat," Chemosphere, vol. 142, pp. 120-127, 2016.

[25] S. Baronti, F. P. Vaccari, F. Miglietta et al., "Impact of biochar application on plant water relations in Vitis vinifera (L.)," European Journal of Agronomy, vol. 53, pp. 38-44, 2014.

[26] D. Laird, P. Fleming, B. Wang, R. Horton, and D. Karlen, "Biochar impact on nutrient leaching from a Midwestern agricultural soil," Geoderma, vol. 158, no. 3-4, pp. 436-442, 2010.

[27] J. Paz-Ferreiro, G. Gascó, B. Gutiérrez, and A. Méndez, "Soil biochemical activities and the geometric mean of enzyme activities after application of sewage sludge and sewage sludge biochar to soil," Biology and Fertility of Soils, vol. 48, no. 5, pp. 511-517, 2012.

[28] A. H. Lone, G. R. Najar, M. A. Ganie, J. A. Sofi, and T. Ali, "Biochar for sustainable soil health: a review of prospects and concerns," Pedosphere, vol. 25, no. 5, pp. 639-653, 2015.

[29] T. J. Clough and L. M. Condron, "Biochar and the nitrogen cycle: introduction," Journal of Environmental Quality, vol. 39, no. 4 , pp. 1218-1223, 2010.

[30] T. J. Clough, L. Condron, C. Kammann, and C. Müller, "A review of biochar and soil nitrogen dynamics," Agronomy, vol. 3, no. 2, pp. 275-293, 2013.

[31] Y. Ding, Y. Liu, W. Wu, D. Shi, M. Yang, and Z. Zhong, "Evaluation of biochar effects on nitrogen retention and leaching in multi-layered soil columns," Water, Air, Soil Pollution, vol. 213, no. 1-4, pp. 47-55, 2010.

[32] R. S. Kookana, "The role of biochar in modifying the environmental fate, bioavailability, and efficacy of pesticides in soils: a review," Australian Journal of Soil Research, vol. 48, no. 6-7, pp. 627-637, 2010.
[33] M. Ventura, G. Sorrenti, P. Panzacchi, E. George, and G. Tonon, "Biochar reduces short-term nitrate leaching from a horizon in an apple orchard," Journal of Environmental Quality, vol. 42, no. 1, pp. 76-82, 2013.

[34] S. Eldridge, C. Chen, Z. Xu, I. Meszaros, and K. Y. Chan, "Greenwaste biochar potentially reduces nitrogen fertiliser losses," in Proceedings of the 19th World Congress of Soil Science: SOil Solutions for a Changing World, Division Symposium 3.2 Nutrient best management practices, International Union of Soil Sciences (IUSS), c/o Institut für Bodenforschung, Universität für Bodenkultur, Brisbane, Australia, August 2010.

[35] Z. Wang, H. Zheng, Y. Luo, X. Deng, S. Herbert, and B. Xing, "Characterization and influence of biochars on nitrous oxide emission from agricultural soil," Environmental Pollution, vol. 174, pp. 289-296, 2013.

[36] A. Taghizadeh-Toosi, T. J. Clough, R. R. Sherlock, and L. M. Condron, "A wood based low-temperature biochar captures $\mathrm{NH}_{3}-\mathrm{N}$ generated from ruminant urine- $\mathrm{N}$, retaining its bioavailability," Plant and Soil, vol. 353, no. 1-2, pp. 73-84, 2012.

[37] B. P. Singh, B. J. Hatton, B. Singh, A. L. Cowie, and A. Kathuria, "Influence of biochars on nitrous oxide emission and nitrogen leaching from two contrasting soils," Journal of Environmental Quality, vol. 39, no. 4, pp. 1224-1235, 2010.

[38] E. W. Bruun, D. Müller-Stöver, P. Ambus, and H. HauggaardNielsen, "Application of biochar to soil and $\mathrm{N}_{2} \mathrm{O}$ emissions: Potential effects of blending fast-pyrolysis biochar with anaerobically digested slurry," European Journal of Soil Science, vol. 62, no. 4, pp. 581-589, 2011.

[39] Y. Zheng, Q. Yu, H. Wang et al., "Preparation of biochars from biogas residue and adsorption of ammonia-nitrogen in biogas slurry," CIESC Journal, vol. 65, no. 5, pp. 1856-1861, 2014.

[40] Y. Guo, H. Tang, G. Li, and D. Xie, "Effects of cow dung biochar amendment on adsorption and leaching of nutrient from an acid yellow soil irrigated with biogas slurry," Water, Air, and Soil Pollution, vol. 225, no. 1, pp. 1-13, 2014.

[41] S. Sekar, R. D. Hottle, and R. Lal, "Effects of biochar and anaerobic digester effluent on soil quality and crop growth in Karnataka, India," Agricultural Research, vol. 3, no. 2, pp. 137147, 2014.

[42] L. Trakal, V. Veselská, I. Šafařík, M. Vítková, S. Číhalová, and M. Komárek, "Lead and cadmium sorption mechanisms on magnetically modified biochars," Bioresource Technology, vol. 203, pp. 318-324, 2016.

[43] M. H. Salehi, O. H. Beni, H. B. Harchegani, I. E. Borujeni, and H. R. Motaghian, "Refining soil organic matter determination by loss-on-ignition," Pedosphere, vol. 21, no. 4, pp. 473-482, 2011.

[44] J. Wang, X. Wang, and J. Zhang, "Evaluating loss-on-ignition method for determinations of soil organic and inorganic carbon in arid soils of Northwestern China," Pedosphere, vol. 23, no. 5, pp. 593-599, 2013.

[45] P. Jiang, T. Lei, X. Liu, Y. Wu, X. Li, and Q. Wang, "Principles and experimental verification of capillary suction method for fast measurement of field capacity," Transactions of the CSAE, vol. 22, no. 7, pp. 1-5, 2006.

[46] X. Xie, L. Wang, and S. Wang, Observation and Analysis of Water Environment Factors, Standard Press of China, Beijing, China, 1998.

[47] W. E. Federation and American Public Health Association, Standard Methods for the Examination of Water and Wastewater, American Public Health Association (APHA), Washington, Wash, USA, 2005. 
[48] H. Yin and M. Kong, "Simultaneous removal of ammonium and phosphate from eutrophic waters using natural calcium-rich attapulgite-based versatile adsorbent," Desalination, vol. 351, pp. 128-137, 2014.

[49] Z. Feng, "Experimental study on removal efficiency of ammonia nitrogen by active carbon and active zeolite," Environmental Engineering, vol. 27, no. S1, pp. 44-47, 2009.

[50] R. I. McDonald, K. F. Weber, J. Padowskic, T. Boucher, and D. Shemie, "Estimating watershed degradation over the last century and its impact on water-treatment costs for the world's large cities," Proceedings of the National Academy of Sciences of the United States of America, vol. 113, no. 32, pp. 9117-9122, 2016.

[51] C. Stoquart, P. Servais, and B. Barbeau, "Ammonia removal in the carbon contactor of a hybrid membrane process," Water Research, vol. 67, pp. 255-266, 2014.

[52] N. Ando, Y. Matsui, R. Kurotobi, Y. Nakano, T. Matsushita, and K. Ohno, "Comparison of natural organic matter adsorption capacities of super-powdered activated carbon and powdered activated Carbon," Water Research, vol. 44, no. 14, pp. 4127-4136, 2010.

[53] C. Jung, J. Heo, J. Han et al., "Hexavalent chromium removal by various adsorbents: powdered activated carbon, chitosan, and single/multi-walled carbon nanotubes," Separation and Purification Technology, vol. 106, pp. 63-71, 2013.

[54] J. Yu, L. Lv, P. Lan, S. Zhang, B. Pan, and W. Zhang, "Effect of effluent organic matter on the adsorption of perfluorinated compounds onto activated carbon," Journal of Hazardous Materials, vol. 225-226, pp. 99-106, 2012.

[55] B. R. Müller, "Effect of particle size and surface area on the adsorption of albumin-bonded bilirubin on activated carbon," Carbon, vol. 48, no. 12, pp. 3607-3615, 2010.

[56] K. A. Spokas, J. M. Novak, and R. T. Venterea, "Biochar's role as an alternative $\mathrm{N}$-fertilizer: ammonia capture," Plant and Soil, vol. 350, no. 1-2, pp. 35-42, 2012.

[57] B. Vandecasteele, T. Sinicco, T. D’Hose, T. Vanden Nest, and C. Mondini, "Biochar amendment before or after composting affects compost quality and $\mathrm{N}$ losses, but not P plant uptake," Journal of Environmental Management, vol. 168, pp. 200-209, 2016.

[58] H. Iqbal, M. Garcia-Perez, and M. Flury, "Effect of biochar on leaching of organic carbon, nitrogen, and phosphorus from compost in bioretention systems," Science of the Total Environment, vol. 521-522, pp. 37-45, 2015.

[59] W. Liu, Y. Liu, X. Gao, M. Yang, Y. Wang, and J. Dai, "Effects of biomass charcoals on retention of ammonium nitrogen in soil," Journal of Agro-Environment Science, vol. 31, no. 5, pp. 962-968, 2012.

[60] Z. Zeng, S. Zhang, T. Li et al., "Sorption of ammonium and phosphate from aqueous solution by biochar derived from phytoremediation plants," Journal of Zhejiang University: Science B, vol. 14, no. 12, pp. 1152-1161, 2013.

[61] X. Gai, H. Liu, and L. Zhai, "Effects of corn-stalk biochar on inorganic nitrogen leaching from soil," Journal of AgroEnvironment Science, vol. 34, no. 2, pp. 310-318, 2015.

[62] S. Kizito, S. Wu, W. Kipkemoi Kirui et al., "Evaluation of slow pyrolyzed wood and rice husks biochar for adsorption of ammonium nitrogen from piggery manure anaerobic digestate slurry," Science of the Total Environment, vol. 505, pp. 102-112, 2015.

[63] D. N. Kothawala and T. R. Moore, "Adsorption of dissolved nitrogen by forest mineral soils," Canadian Journal of Forest Research, vol. 39, no. 12, pp. 2381-2390, 2009.
[64] Z. Sun and J. Liu, "Study on vertical movement of nitrate nitrogen and ammonia nitrogen in typical Calamagrostis angustifolia Wetland Soil of Sanjiang Plain," Journal of Soil and Water Conservation, vol. 21, no. 6, pp. 25-30, 2007.

[65] D. Cavalli, G. Consolati, P. Marino, and L. Bechini, "Measurement and simulation of soluble, exchangeable, and nonexchangeable ammonium in three soils," Geoderma, vol. 259260, pp. 116-125, 2015.

[66] G. N. Paranavithana, K. Kawamoto, Y. Inoue et al., "Adsorption of $\mathrm{Cd}^{2+}$ and $\mathrm{Pb}^{2+}$ onto coconut shell biochar and biochar-mixed soil," Environmental Earth Sciences, vol. 75, no. 6, pp. 1-12, 2016.

[67] Z. M. Solaiman and H. M. Anawar, "Application of biochars for soil constraints: challenges and solutions," Pedosphere, vol. 25, no. 5, pp. 631-638, 2015.

[68] J. Lehmann and S. Joseph, "Biochar for environmental management: science, technology and implementation," in Routledge, 2015.

[69] X. Cheng, Y. M. Li, B. Wang, and J. M. Jiang, "Photocatalytic property of rice husk char/ $\mathrm{TiO}_{2}$ composite prepared by lowtemperature method," Materials Science Forum, vol. 848, pp. 7781, 2016.

[70] P. Sudhakar, I. D. Mall, and V. C. Srivastava, "Adsorptive removal of bisphenol-A by rice husk ash and granular activated carbon-A comparative study," Desalination and Water Treatment, vol. 57, no. 26, pp. 12375-12384, 2016.

[71] M. Li, S. C. Wu, Y. Peng, and Y. Shih, "Adsorption of volatile organic vapors by activated carbon derived from rice husk under various humidity conditions and its statistical evaluation by linear solvation energy relationships," Separation and Purification Technology, vol. 170, pp. 102-108, 2016. 

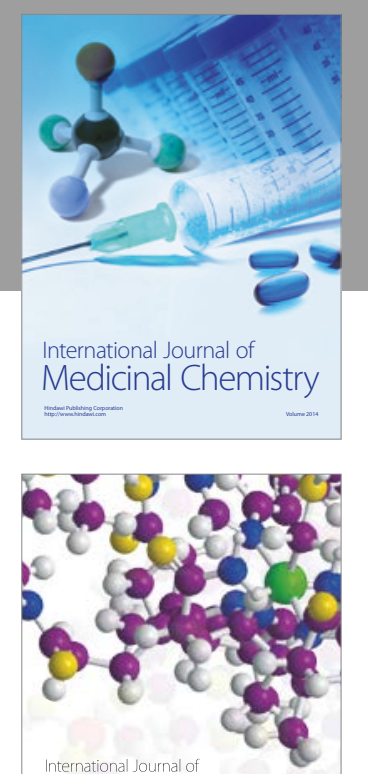

Carbohydrate Chemistry

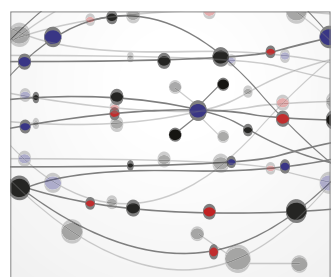

The Scientific World Journal
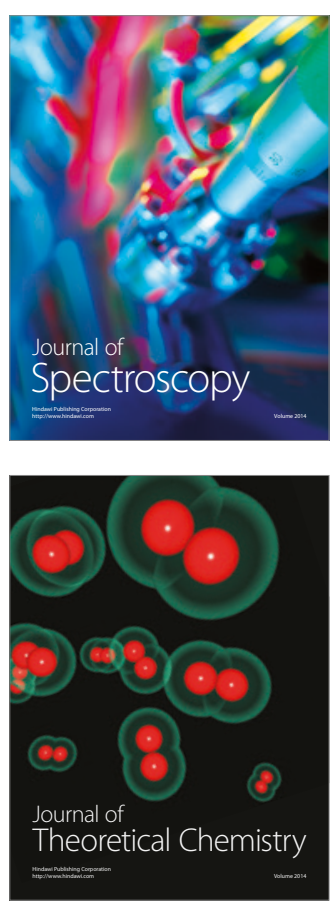
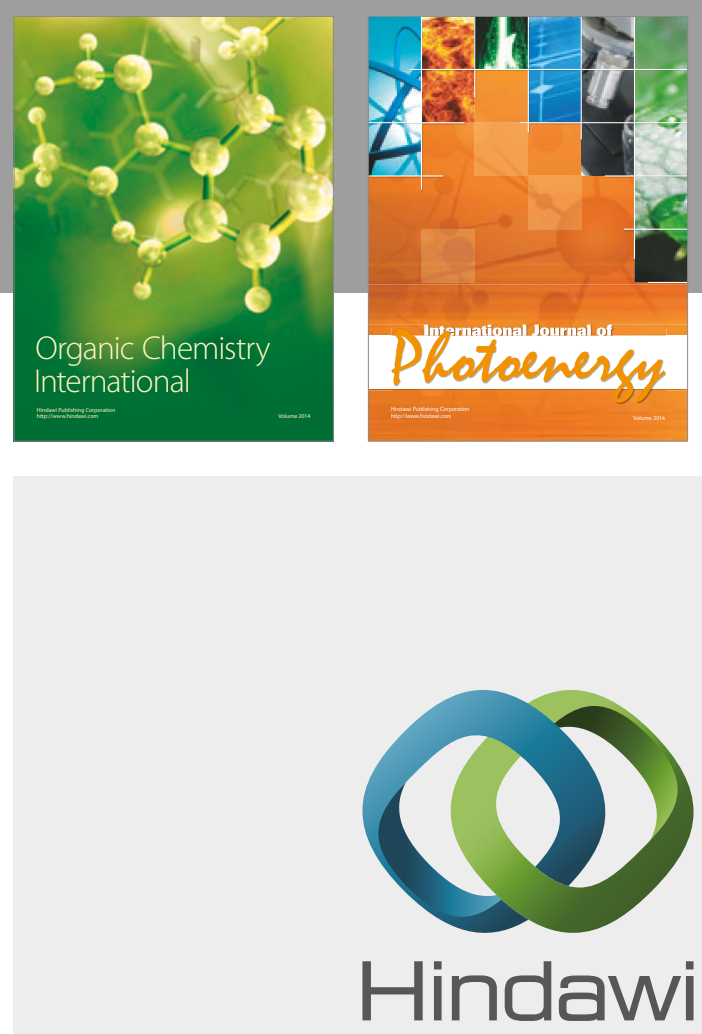

Submit your manuscripts at

https://www.hindawi.com

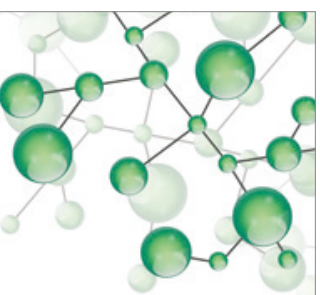

International Journal of

Inorganic Chemistry

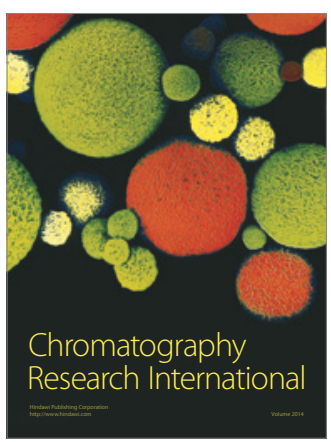

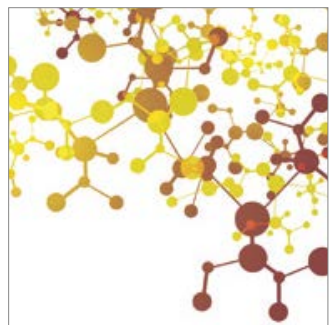

Applied Chemistry
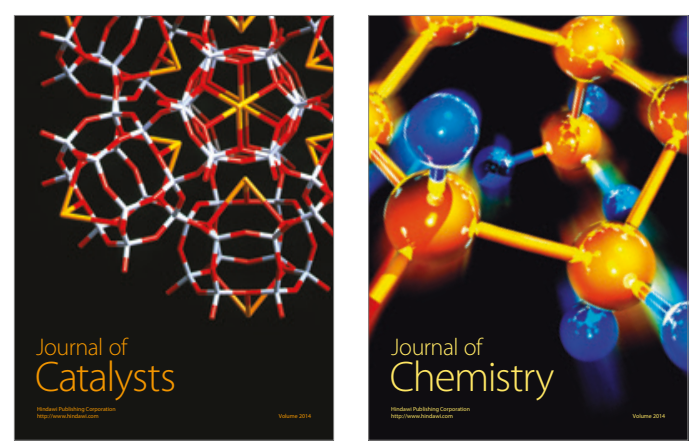
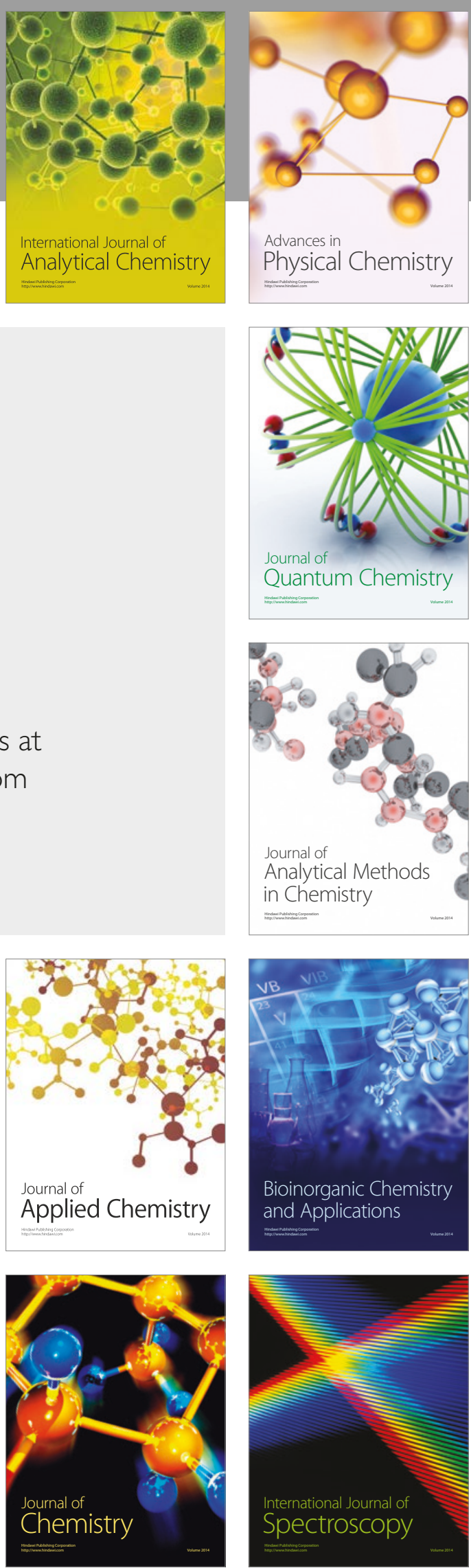